\title{
Impact of Financialization on Operating Profit of Manufacturing Listed Companies
}

\author{
Gan Shengdao ${ }^{1, \mathrm{a}}$, Wang Qingying ${ }^{1, \mathrm{a}}$, Zhang Qiya ${ }^{2, \mathrm{~b}}$ \\ ${ }^{1}$ Sichuan University, Business School, Chengdu, P. R. China \\ ${ }^{2}$ Chongqing Chang'an Automobile Co., Ltd, Financial operation Department, Chongqing, P. R. China
}

\begin{abstract}
This study employs a sample of manufacturing listed companies in China from fiscal year 2008 to 2018, analyzes their financial position and operating performance, and explores the impact of financialization on their operating profits. The results suggest that the financialization of manufacturing listed companies will restrain the growth of operating profit, that is the "crowding out" effect. This paper reminds the listed companies' controlling shareholders of the economic consequences of financialization at the micro level and the significance of improving the company's core competitiveness, further promotes companies to strengthen the internal control of financialization for sustainable development of the companies.
\end{abstract}

\section{Introduction}

Since the 19th National Congress of the Communist Party of China in 2017, government have proposed and advocated high-quality development of enterprises. In fact, some listed companies in the non-financial industry are constantly involved in the financial industry in addition to their main businesses, holding growing financial assets. It is worth discussing whether it will affect the quality of enterprise development

As the core of the development of the real industry, manufacturing companies play an important role in creating social wealth. However, due to the inherent limitations of the different profitability of each link in the value chain and the difficulties in rising labor costs, insufficient innovation and overcapacity, the return on investment of the real industry has gradually declined since 2007 [1]. Compared with the manufacturing industry, the financial industry has a greater profit attraction. As a result, manufacturing companies began to make financial investment unduly [2]. Many listed companies in China have participated in financial market activities, which once aroused attention and controversy from all sectors of society. For example, Jiangsu Yanghe Brewery Joint-Stock Co., Ltd. has been purchasing financial assets continuously since 2011. According to the 2018 annual report, Yanghe company has accumulated a cumulative investment of 20.619 billion yuan in financial assets, accounting for $41.6 \%$ of total assets.

In fact, non-financial companies gradually participate in financial investment activities and purchase large amounts of financial assets actively, which is an important evidence of financialization at the micro level [3][4]. After observing the proportion of financial assets in total assets of listed manufacturing companies in China from 2008 to 2018, we found the proportion of financial assets have not exceeded $10 \%$ of the total assets on average, but from a trend perspective, the ratio of financial assets to total assets has been increasing and the growth rate has accelerated significantly in recent years. Dividing financial assets into monetary financial assets and non-monetary financial assets, we found that manufacturing listed companies are still mainly investing in non-monetary financial assets. Among non-monetary financial assets, manufacturing listed companies prefer to invest in long-term equity investments and availablefor-sale financial assets. In addition, the investment of listed manufacturing companies in transactional financial assets and investment property has increased significantly in the past three years. In a word, both nonmonetary financial assets and monetary financial assets are on the rise, and the growth rate is relatively fast in recent years.

Another evidence of financialization at the micro level is that the capital accumulation model of nonfinancial enterprises has changed, and the source of corporate profits has shifted from the traditional production and trade process to the financial channel [5][6]. We have observed the trends in the proportion of investment income in total profits of listed manufacturing companies in China from 2008 to 2018. On average, Chinese manufacturing listed companies' income from financial investment accounts for less than $20 \%$ of total profits, which indicates that the current real industry income is still mainly from real operations. However, the ratio has shown a rapid upward trend in recent years, which deserves the attention of the industry.

a18487251637@163.com; bqiya_zhang@163.com 
Undoubtedly, financialization is gradually affecting the development of the real industry at the micro level. As the backbone of economic development, manufacturing listed companies should have absorbed investment from the capital market to help the development of the main industry [7], but they have begun to actively participate in financial investment in the context of the financial investment boom and their own development difficulties. Increasing investment in the financial industry on the one hand occupies the operating funds of manufacturing companies, which may inhibit corporate innovation and cause a "crowding out" effect [8], but on the other hand, it may also increase the companies' capital reserves, which can alleviate the liquidity pressure of companies to a certain extent, and cause a "boosting" effect. For listed companies in the manufacturing industry, will increasing corporate financialization activities help the development of manufacturing companies to have a "boosting" effect because they receive funding support from investment income? Will financialization bring a "crowding out" effect to manufacturing companies because the allocation of resources to financial assets will weaken the development of the company's main business? Based on these two effects, to explore the impact of financialization activities on the real industry, this paper will focus on manufacturing listed companies and study the impact of corporate financialization on operating profits.

\section{Theoretical analysis and Hypothesis}

Discussions in the existing literature on the impact of financialization on companies can be divided into positive and negative aspect. Tornell A. believes that companies invest in financial assets with strong liquidity in order to deal with uncertainty, and financialization can broaden corporate financing channels [9]. Demif F. believes financial assets provide alternatives for corporate investment [10]. Theurillat $\mathrm{T}$. believes that financialization is conducive to resource allocation [11]. Investment income can increase the resources which will be invested to the main business to a certain extent. It may also improve the corporate capital structure and enhance financing capabilities. Empirical analysis on financialization by Orhangazi finds that financialization will bring "crowding effect" to physical investment, causing short-termism [12]. At the same time, increasing financial investment will increase the company payment pressure correspondingly, such as dividend, stock repurchase, etc. If the debt burden of the company is increased as a result, the company may occupy the actual investment funds, shorten the company's planning horizon and increase uncertainty. The crowding out effect of financial activities on physical asset investment will reduce the real industry investment rate [1]. Xiao Ming and Cui Chao shows that there is an inverted Ushaped relationship between the degree of financialization of non-financial listed companies and corporate performance [13]. Too high or too low degree of financialization may have a negative impact on corporate performance. Empirical analysis by Du Yong, Zhang Huan and Chen Jianying finds that financialization has significantly affected the development of the main business by reducing corporate innovation and long-term asset investment [14].

Theoretically, the financialization of the physical enterprise has two opposite effects: the "crowding" effect and the "boosting" effect on the development of the main business of the enterprise, thus affecting the operating profit. The ultimate impact of financialization activities on the operating profits of companies should depend on the relative size of the "boosting" effect and the "crowding out" effect. If the "boost" effect caused by financialization is greater than the "crowding out" effect, then the financialization of non-financial enterprises will be beneficial to the development of the real industry. And if the "crowding out" effect caused by financialization is far greater than its "boosting" effect, then the financialization of physical enterprises will cause capital mismatch problems and eventually negatively affect operating profits. Accordingly, this paper proposes the following two opposing hypotheses: For manufacturing listed companies, the "boosting" effect of financialization is dominant, and financialization is positively affecting operating profit(H1). And for manufacturing listed companies, the "crowding out" effect of financialization is dominant, and financialization negatively affects operating profit(H2).

Does the impact of financialization on the operating profits of manufacturing companies vary depending on the nature of property rights? On the one hand, the ultimate actual controller of a state-owned manufacturing enterprise is the national government, which usually has a strong background and a high reputation, and its operating conditions and profitability are relatively stable. And in the context of government support, state-owned enterprises often have easier access to government funding support and financial institution loans [15]. Because there are weaker financing constraints, the "boosting" effect of financialization activities should not be too obvious in state-owned enterprises. In comparison, the motivation of non-stateowned enterprises to conduct financial activities to diversify business risks in their main businesses is stronger, increasing the possibility that financial activities will "boost" their main businesses. On the other hand, in the face of the huge profit spread between the manufacturing and financial industries, non-state-owned manufacturing enterprises are more likely to choose financialized investment as a substitute for physical investment due to insufficient investment supervision. And non-state-owned enterprises are more likely to engage in short-sighted behaviors such as financial speculative arbitrage [16] [17], abandon research and development innovation, and give up investing in longterm assets, causing a "crowding out" effect on the physical manufacturing industry. Therefore, this paper assumes that the financialization of non-state-owned enterprises has a greater damaging effect on operating profit, and puts forward the following hypothesis: Compared with state-owned manufacturing listed companies, non-state-owned enterprises' financialization has more significant damaging effects on operating profits(H3). 


\section{Data and Research Design}

\subsection{Data}

This paper selects China A-share listed manufacturing companies from 2008 to 2018 as the research sample. The data source of this paper is CSMAR database and WIND Database. The data is processed by Stata 15.1 software. In order to make the results meaningful, we eliminated ST, * ST companies, companies that have been suspended. We eliminated companies with zero total assets, an asset-liability ratio of less than 0 or greater than 1 , and zero sales revenue. We also exclude companies listed in 2017 and beyond to ensure that the sample has at least two consecutive observations. At the same time, we also used the Winsorize method to eliminate the extreme value of $1 \%$. After the above processing, 12,549 valid observations were finally determined in this paper.

\subsection{Variable Description}

\subsubsection{Explained variable}

To explore the impact of the degree of financialization on operating profit, it should be based on operating profit after divesting financialized profit:

Operating rate of return $(\mathrm{OR})=$ (Total profits Financialized profit) / (Total assets -Financialized assets)

Of which: Financialization profit $=$ interest income + fair value gains and losses + investment income + net exchange income

\subsubsection{Explanatory variable}

Compared with the investment profit proportion method and investment profit distribution method [17], the Financial asset rate method can better reflect the company's intention to allocate resources between operating assets and financialized assets. Therefore, this paper uses the Financial asset rate method, and selects the financialized asset rate (FAR) as an indicator to measure the degree of financialization of the enterprise. The calculation formula is as follows:

Financialized asset rate $=$ financialized assets $/$ total assets

Of which: Financialized assets $=$ cash and cash equivalents held for financial purposes + trading financial assets + available for sale financial assets + investments held to maturity + long-term equity investments + investment property

According to the purpose of holding cash by enterprises, we divide cash and cash equivalents into those held for business purposes and those held for financial purposes. This view of this paper is also in line with James. C Van Horne's argument that cash can be divided into three categories: ready cash segment, controllable cash segment, and free cash segment [18]. Ready cash segment and controllable cash segment are cash held by the enterprise in the future to maintain daily operating activities, that is, cash held for business purposes. And free cash segment should be cash held for financial investment purposes. Because there is no classification of cash and cash equivalents in the statement of financial position and its notes according to their holding purpose, and it is impossible to accurately predict the flow of funds in all business operations, we derived the calculation formula for cash and cash equivalents held for financial purposes based on the assumption that the cash and cash equivalents held for financial purposes to cash and cash equivalents held for business purposes are the same as the ratio of nonmonetary financial assets to non-monetary operating assets:

Cash and cash equivalents held for financial purposes $=$ total cash and cash equivalents $\times$ [non-monetary financial assets / (non-monetary financial assets + nonmonetary operating assets)]

\subsubsection{Control variable}

a) SIZE: Natural logarithm of total assets.

b) ALT: Total liabilities / total assets.

c) GROWTH: One-year growth rate of a firm's operating income.

d) $O C$ : The sum of the shareholdings of the top ten shareholders of listed companies.

e) $C G$ : Corporate Governance Composite Index. Refer to Li Minghui et al. to synthesize six corporate governance indicators into one comprehensive indicator [17] [19] [20].

f) Nature: Dummy variable that takes the value of 1 if a firm is state-owned enterprise, and 0 otherwise.

\subsection{Equations}

A multiple regression model is established to examine the impact of corporate financialization on operating profit:
$O R_{i, t}=\beta_{0}+\beta_{1} \times F A R_{i, t}+\beta_{2} \times S I Z E_{i, t}+$ $\beta_{3} \times A L T_{i, t}+\beta_{4} \times G R O W T H_{i, t}+\beta_{5} \times O C_{i, t}+$ $\beta_{6} \times C G_{i, t}+\beta_{7} \times Y E A R_{i, t}+\varepsilon_{i, t}$

\subsection{Research design}

\subsubsection{Descriptive statistics}

Table 1 is a descriptive statistical table of the variables. From the total sample, the average financial assets rate of listed manufacturing companies in China is $5.18 \%$, the minimum value of financialization rate is 0 , the maximum is 0.46 , and the standard deviation is 0.085 . This shows that on the whole, the degree of financialization of China's manufacturing listed 
companies is not so high. However, in the process of data cleaning, we found that some manufacturing companies are financially as high as $90 \%$, indicating that there are radical financial activities in listed companies.

TABLE I. DESCRIPTIVE STATISTICS

\begin{tabular}{|l|l|l|l|l|l|}
\hline $\begin{array}{l}\text { Variabl } \\
\text { es }\end{array}$ & Obs. & $\begin{array}{l}\text { Averag } \\
\text { e }\end{array}$ & Std. & Min. & Max. \\
\hline OR & 12549 & 0.0533 & 0.0688 & $\begin{array}{l}- \\
0.200 \\
4\end{array}$ & 0.2678 \\
\hline FAR & 12549 & 0.0518 & 0.0847 & 0 & 0.4607 \\
\hline SIZE & 12549 & $\begin{array}{l}21.845 \\
8\end{array}$ & 1.1394 & $\begin{array}{l}19.66 \\
96\end{array}$ & $\begin{array}{l}25.280 \\
5\end{array}$ \\
\hline ALT & 12549 & 0.3962 & 0.1967 & $\begin{array}{l}0.048 \\
2\end{array}$ & 0.8692 \\
\hline $\begin{array}{l}\text { GROW } \\
\text { TH }\end{array}$ & 12549 & 0.1672 & 0.3257 & -.7970 & 7.6193 \\
\hline OC & 12549 & 56.167 & 15.056 & 15.77 & 100 \\
\hline
\end{tabular}

TABLE II. CORRELATION COEFFICIENT BETWEEN STUDY VARIABLES

\begin{tabular}{|c|c|c|c|c|c|c|c|}
\hline & OR & FAR & SIZE & ALT & GROWTH & OC & CG \\
\hline OR & 1 & $\overline{-}-076^{* * *}$ & $0.097^{* * *}$ & $0.425^{* * *}$ & $0.056^{* * *}$ & $0.048^{* * *}$ & $0.015^{*}$ \\
\hline FAR & -0.003 & 1 & $0.235^{* * *}$ & $0.112^{* * *}$ & -0.012 & $\overline{0} .054^{* * *}$ & $-\overline{0.043 * * *}$ \\
\hline SIZE & $0.033^{* * *}$ & $0.092 * * *$ & 1 & $0.491 * * *$ & 0.003 & $0.045^{* * *}$ & $0.040^{* * * *}$ \\
\hline ALT & $0.387 * * *$ & $-0.019^{* *}$ & $0.485^{* * *}$ & 1 & $-0.017^{*}$ & $0.078^{* * *}$ & $0.023^{* * * *}$ \\
\hline GROWTH & $0.034 * * *$ & $-0.015^{*}$ & -0.001 & -0.009 & 1 & $0.029 * * *$ & 0.002 \\
\hline OC & $0.033^{* * *}$ & $\overline{0} .040^{* * * *}$ & $0.031^{* * *}$ & $0.077 * * *$ & $0.022 * *$ & 1 & 0.005 \\
\hline CG & 0.013 & $\overline{-}-028^{* * *}$ & $0.034^{* * *}$ & $-0.022 * *$ & -0.001 & 0.005 & 1 \\
\hline
\end{tabular}

Notes: Pearson correlations (left below) and spearman correlations (right above).

$*, * *, * * *$ significant at $0.10,0.05$ and 0.01 levels.

\subsubsection{Regression analysis}

After passing the Hausman test, a fixed-effects model was selected for regression analysis, and regression analysis tests were performed on the full sample, the state-owned enterprise sub-sample, and the non-stateowned enterprise sub-sample. Table 3 reports the results

\begin{tabular}{|l|l|l|l|l|l|}
\hline & & 8 & 4 & 00 & \\
\hline CG & 12549 & 0.5518 & 0.4973 & 0 & 1 \\
\hline
\end{tabular}

\subsubsection{Correlation analysis}

Table 2 is the correlation coefficient table of the main variables. This table shows that for the two variables of financialized assets rate (FAR) and operating return rate (OR), both the Pearson coefficient and the Spearman coefficient have a negative correlation, where the Spearman coefficient passed the significance test at the level of $1 \%$, which supports the hypothesis 2 in this paper, and rejects the hypothesis 1 to a certain extent.

TABLE III. REGRESSION ANALYSIS

\begin{tabular}{|l|l|l|l|}
\hline & $\begin{array}{l}\text { All sample } \\
\text { (Std.) }\end{array}$ & SOEs & Non-SOEs \\
\hline \multirow{2}{*}{ FAR } & $\begin{array}{l}-0.0429 * * * \\
(0.00949)\end{array}$ & $\begin{array}{l}-0.00719 \\
(0.0173)\end{array}$ & $\begin{array}{l}-0.0559^{* * *} \\
(0.0114)\end{array}$ \\
\hline \multirow{2}{*}{ SIZE } & $\begin{array}{l}-0.00487 * * * \\
(0.000907)\end{array}$ & $\begin{array}{l}-0.00867 * * * \\
(0.00169)\end{array}$ & $\begin{array}{l}-0.00284 * * \\
(0.00113)\end{array}$ \\
\hline \multirow{2}{*}{ ALT } & $\begin{array}{l}-0.130 * * * \\
(0.00483)\end{array}$ & $\begin{array}{l}-0.130 * * * \\
(0.00924)\end{array}$ & $\begin{array}{l}-0.123 * * * \\
(0.00578)\end{array}$ \\
\hline \multirow{2}{*}{ GROWTH } & $\begin{array}{l}0.00667 * * * \\
(0.00148)\end{array}$ & $\begin{array}{l}0.00422 \\
(0.00310)\end{array}$ & $\begin{array}{l}0.00693 * * * \\
(0.00168)\end{array}$ \\
\hline OC & $3.77 \mathrm{e}-05$ & -0.000102 & $0.000118^{* *}$ \\
\hline
\end{tabular}




\begin{tabular}{|c|c|c|c|}
\hline & $(4.99 \mathrm{e}-05)$ & $(0.000120)$ & $(5.61 \mathrm{e}-05)$ \\
\hline CG & $\begin{array}{l}0.00180 \\
(0.00117) \\
\end{array}$ & $\begin{array}{l}-0.000751 \\
(0.00219) \\
\end{array}$ & $(0.00140)$ \\
\hline YEAR & Control & Control & Control \\
\hline Constant & $\begin{array}{l}0.209 * * * \\
(0.0196)\end{array}$ & $\begin{array}{l}0.297 * * * \\
(0.0358)\end{array}$ & $(0.0246)$ \\
\hline Observations & 12,549 & 3,446 & 9,103 \\
\hline R-squared & 0.082 & 0.096 & 0.072 \\
\hline
\end{tabular}

Notes: Standard deviation in brackets. ${ }^{*}, * *, * *$ significant at $0.10,0.05$ and 0.01 levels.

For the sub-sample, the regression coefficient of FAR in the non-state-owned enterprise sub-sample is 0.056 , and it is significant at the level of $1 \%$; while in the state-owned enterprise sub-sample, the FAR coefficient is -0.007 . And the absolute value of the FAR coefficient of non-state-owned manufacturing listed companies is larger than that of state-owned manufacturing listed companies. The results confirm that among the listed companies in the manufacturing industry, the non-stateowned enterprises' financialization activities have a stronger damaging effect on their operating profits, which validates the hypothesis 3 .

\subsubsection{Robustness test}

\subsubsection{Non-linear relationship}

Considering that there may be a non-linear relationship between the degree of financialization and its operating profit, this paper incorporates the square of FAR (FAR2) in the empirical model to construct a new non-linear model and perform regression analysis again. The test results show that the regression coefficient of FAR is still significantly negative, and the sign of the regression coefficient of the square of FAR (FAR2) is negative but not significant. It is proved that there is not enough evidence to show that there is a non-linear relationship between the financialization degree and operating returns of listed manufacturing companies.

\subsubsection{Alternative explanatory variables}

In order to ensure the reliability of the empirical results, this paper also conducts a robustness test by replacing the explanatory variables. Considering the perspective of cash flow, we use the financial investment rate (FIR) instead of the financial asset rate (FAR) as a substitute variable to measure the financialization level of listed manufacturing companies for robustness testing. Financial investment rate (FIR) is equal to cash paid for investment divided by investment cash outflow [21]. The test results show that the direction and significance of the regression coefficient between each variable and the explained variable (OR) are consistent with the original regression results, that is, there is no difference in the results of measuring the correlation between the degree of financialization of the company and the operating profit from the perspective of cash flow. Hypothesis 2 and 3 are supported, and hypothesis 1 is rejected.

\section{Conclusion and Suggestions}

This paper examines the impact of financialization on operating profits and finds that for manufacturing listed companies, the "crowding out" effect of financialization on operating profit is stronger than the "boosting" effect. The degree of financialization will negatively affect the operating profit of enterprises, and this effect is more significant in non-state-owned manufacturing enterprises. According to the research of this paper, firstly, manufacturing listed companies need to invest moderately and be alert to the higher the degree of financialization, the lower the company's operating return rate. Manufacturing listed companies should formulate a scientific corporate governance system based on the perspective of high-quality development, properly manage corporate financialization activities, avoid inefficient financialization investment and excessive financialization investment behavior. In addition, the government should promote financial industry reform, strengthen financial supervision, and guide investors to avoid blind financial speculation, so that the financial industry can better serve the real industry. Finally, we also call for the reform of financial statement presentation. Based on the entity's activities, companies could disclose the resource allocation and operating efficiency of the real economy and virtual economy respectively, which will help stakeholders understand the degree and efficiency of corporate financialization better.

\section{References}

1. Zhang Chengsi, Zhang Butan. The Falling Real Investment Puzzle: A View from Financialization[J]. Economic Research Journal,2016,51(12):32-46.

2. Song Jun, Lu Yang. U-shape Relationship between Non-currency Financial Assets and Operating Profit: Evidence from Financialization of Chinese Listed Non-financial Corporates[J]. Journal of Financial Research,2015(06):111-127.

3. Gan Shengdao, Chen Yancun, Wang Wenbing. Research on the Governance of Excessive Financialization of Non-financial Listed Companies $[\mathrm{J}]$. Finance and Accounting Monthly,2016(34):3-5.

4. Chen Yancun, Gan Shengdao. Research on the Trend of Financialization of Manufacturing Enterprises in China and Its Influencing Factors- 
Based on the Perspective of Enterprise Life Cycle [J]. Finance and Accounting Monthly, 2018 (19): 714.

5. Peng Yuchao, Ni Xiaoran, Shen Jie. The Effect of Transforming the Economy from Substantial to Fictitious on Financial Market Stability: An Analysis on Stock Price Crash Risk[J]. Economic Research Journal,2018,53(10):50-66.

6. Dai Ze, Peng Yuchao, Ma Sichao. Understanding the Economic Shifting "from Real to Virtual" from the Micro Perspective: A Literature Review of Corporate Financialization[J]. Foreign Economics and Management,2018,40(11):31-43.

7. Peng Yuchao, Han Xun, Li Jianjun. Economic Policy Uncertainty and Corporate Financialization[J]. China Industrial Economics,2018(01):137-155.

8. Wang Hongjian, Cao Yuqiang, Yang Qing, Yang Zheng. Does the Financialization of Non-financial Enterprises Promote or Inhibit Corporate Innovation[J]. Nankai Business Review,2017,20(01):155-166.

9. Tornell A. Real Vs. Financial Investment Can Tobin Taxes Eliminate the Irreversibility Distortion[J]. Journal of Development Economics, 1990, 32(2): 419-444.

10. Demif F. Capital Market Imperfections and Financialization of Real Sectors in Emerging Markets: Private Investment and Cash Flow Relationship Revisited. 2009, 37(5):953-964.

11. OzgurOrhangazi. Financialisation and Capital Accumulation in the Non-Financial Corporate Sector: A Theoretical and Empirical Investigation On the US Economy: 1973-2003 [J]. Cambridge Journal of Economics, 2008, 32 (6):863-886.

12. Theurillat T., J. Corpataux and O. Crevoisier. Property Sector Financialization: The Case of Swiss Pension Funds ( 1992-2005 ) [J]. European Planning Studies, 2010, 18(2):189-212.

13. Xiao Ming, Cui Chao. Research on the Impact of Financialization on the Performance of Non- financial Listed Companies in China [J]. Communication of Finance and Accounting, 2016 (09): 72-74.

14. Du Yong, Zhang Huan, Chen Jianying. The Impact of Financialization on Future Development of Real Enterprises' Core Business: Promotion or Inhibition. [J]. China Industrial Economics,2017(12):113-131.

15. Deng Chao, Zhang Mei, Tang Ying. Influencing Factors of Financialization of Non-financial Enterprises in China[J]. The Theory and Practice of Finance and Economics, 2017,38(02):2-8.

16. Xu Gang, Wu Wenzhong. The Mystery of Corporate Financial Investment: Earnings Management or Financial Arbitrage? [J]. Securities Market Herald, 2018(08): 20-28.

17. Gan Shengdao, He Yi, Xiao Liang. Is the Financialization Level of Entity Enterprises Influenced by Managers?-Based on the Perspective of Managerial Overconfidence. Contemporary Economic Management, 2008,40(02):11-16.

18. James. C Van Horne. Modern Enterprise Financial Management (13th Edition) [M]. Beijing: Tsinghua University Press, 2009.

19. Li Minghui, Liu Xiaoxia. On the Relationship between Client Importance and Audit Quality: Moderating Effects of Corporate Governance[J]. Journal of Finance and Economics,2013,39(03):6474.

20. He Yi, Gan Shengdao, Fu Xinhong, Chen Yongzhi. Does the personality of the chairman of an agricultural company affect the level of financialization of the company? Based on evidence from Shanghai and Shenzhen A-share agricultural listed companies[J]. Rural Economy,2017(09):82-87.

21. Liu Lina, Ma Yamin. Financialization, Excess Leverage and the Risk of Stock Price Crash of Real Business Entities: A Test Based on the Perspective of Investment of Listed Companies[J]. Journal of Yunnan Finance and Trade Institute,2018,34(03):4155. 